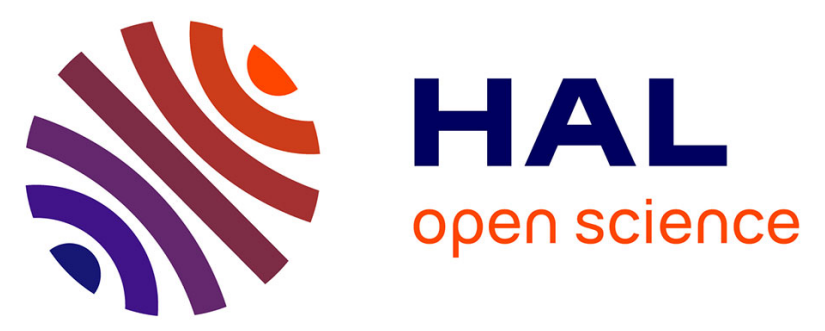

\title{
Comparative inhibitory effect of prenylated coumarins, ferulenol and ferprenin, contained in the 'poisonous chemotype' of Ferula communis on mammal liver microsomal VKORC1 activity.
}

Marie-Sophie Louvet, Gilbert Gault, Sebastien Lefebvre, Florence Popowycz, Manon Boulven, Stéphane Besse, Etienne Benoit, Virginie Lattard, Denis Grancher

\section{- To cite this version:}

Marie-Sophie Louvet, Gilbert Gault, Sebastien Lefebvre, Florence Popowycz, Manon Boulven, et al.. Comparative inhibitory effect of prenylated coumarins, ferulenol and ferprenin, contained in the 'poisonous chemotype' of Ferula communis on mammal liver microsomal VKORC1 activity.. Phytochemistry, 2015, 118 (118), pp.124-130. 10.1016/j.phytochem.2015.08.012 . hal-01577246

\author{
HAL Id: hal-01577246 \\ https://hal.science/hal-01577246
}

Submitted on 25 Aug 2017

HAL is a multi-disciplinary open access archive for the deposit and dissemination of scientific research documents, whether they are published or not. The documents may come from teaching and research institutions in France or abroad, or from public or private research centers.
L'archive ouverte pluridisciplinaire HAL, est destinée au dépôt et à la diffusion de documents scientifiques de niveau recherche, publiés ou non, émanant des établissements d'enseignement et de recherche français ou étrangers, des laboratoires publics ou privés. 
Comparative inhibitory effect of prenylated coumarins, ferulenol and ferprenin, contained in the 'poisonous chemotype' of Ferula communis on mammal liver microsomal VKORC1 activity.

Marie-Sophie LOUVET $^{1, *}$, Gilbert GAULT ${ }^{1, *}$, Sébastien LEFEBVRE$^{1}$, Florence POPOWYCZ ${ }^{2}$, Manon BOULVEN ${ }^{2}$, Stéphane BESSE${ }^{1}$, Etienne BENOIT ${ }^{1}$, Virginie LATTARD $^{1}$, Denis GRANCHER ${ }^{1}$.

${ }^{1}$ USC 1233 INRA-Vetagro Sup, Veterinary School of Lyon, 1 avenue Bourgelat, 69280 Marcy l'Etoile, France

${ }^{2}$ Laboratoire de Chimie Organique et Bio-organique, Institut National des Sciences Appliquées (INSA-Lyon), ICBMS-CNRS-UMR 5246, 20 Avenue Albert Einstein, F-69621 Villeurbanne Cedex

Corresponding author: Virginie Lattard

USC 1233 INRA-Vetagro Sup 69280 Marcy l’Etoile, France

Email: virginie.lattard@ vetagro-sup.fr; Phone: +33-(0)4 788727 27; Fax: +33-(0)4 788705 16

\footnotetext{
* Authors contributed equally to this article
} 


\begin{abstract}
Two distinguishable chemotypes of Ferula communis have been described: the 'nonpoisonous' chemotype, containing as main constituents the daucane esters; and the 'poisonous' chemotype containing prenylated coumarins, such as ferulenol and ferprenin. Ferulenol and ferprenin are 4-oxygenated molecules such as dicoumarol and warfarin, the first developed antivitamin K molecules. Antivitamin K molecules specifically inhibit VKORC1, an enzyme essential for recycling vitamin $\mathrm{K}$. This latest is involved in the activation of clotting factors II, VII, IX, X. The inhibiting effect of ferulenol on VKORC1 was shown in rat, but not for species exposed to $F$. communis while in vivo studies suggest differences between animal susceptibility to ferulenol. The inhibiting effect of ferprenin on VKORC1 was never demonstrated. The aim of this study was to compare the inhibiting effect of both compounds on VKORC1 of different species exposed to $F$. communis. Vitamin K epoxide activity was evaluated for each species from liver microsomes and inhibiting effect of ferulenol and ferprenin was characterized. Ferulenol and ferprenin were shown to be able to inhibit VKORC1 from all analyzed species. Nevertheless, susceptibility to ferulenol and ferprenin presented differences between species, suggesting a different susceptibility to 'poisonous' chemotypes of $F$. communis.
\end{abstract}

Keywords: Ferula communis L. (Apiaceae), Ferulenol, Ferprenin, VKORC1, inhibition constant, interspecies variability

\footnotetext{
Abbreviations : VKOR, Vitamine K epoxide reductase; VKORC1, Vitamin K epoxide reductase complex subunit 1; Vitamin $\mathrm{K}>\mathrm{O}$, vitamin $\mathrm{K}$ epoxide.
} 


\section{INTRODUCTION}

Ferula communis L. (Apiaceae) is a perennial and robust weed, native to the Mediterranean basin. Its presence was reported in Syria, Turkey, North Africa, Italy, Sardinia, Portugal, Greece, Croatia, Albania and Palestine (Cauwet Marc, 1981; Infante, 1965). Consumption of F. communis L. has been reported to be associated to an hemorrhagic syndrome, also called ferulosis, often fatal in the absence of treatment (Benzaldi, 1988; Cauwet Marc 1990). This intoxication affected almost all mammals and the National Center of Veterinary Toxicology of Lyon (France) diagnosed 28 clinical cases of Ferula communis intoxication in cattle, sheep, pig and horse from 1990 to 2013 (Gault et al, 2013). Even man may be affected after an uncontrolled therapeutic use of Ferula extract (Cornevin et al, 1887; Lannehoa et al, 1998).

Two distinguishable chemotypes of $F$. communis L. were reported: the 'non-poisonous' chemotype and the 'poisonous' chemotype associated to the hemorrhagic syndrome (Benkhalti and Lamnaouer, 1994; Sacchetti et al, 2003). Different chemical investigations have reported the presence of daucane esters or drimane ethers, as main constituents in the 'non-poisonous' chemotype, according to the geographic area and the presence of prenylated coumarins as main constituents in the 'poisonous' chemotype (Appendino et al, 1987; Appendino et al, 2001; Fraigui et al, 2001; Miski and Mabry, 1985; Valle et al, 1987; Rubiolo et al, 2006). Among the prenylated coumarins of the toxic variety, both ferulenol, a 4hydroxycoumarin derivative, and ferprenin, a pyrane (3,2-c) coumarin derivative (Appendino et al, 1988; Carboni et al, 1964) (Figure 1) could affect blood clotting, as described for other 4-oxygenated coumarin derivatives such as dicoumarol or warfarin, the first developed antivitamin $\mathrm{K}$ molecules used in human medicine and as rodenticide for pest control. 4-hydroxycoumarin derivatives, also designed as antivitamin $\mathrm{K}$ molecules were reported to specifically inhibit VKORC1, an enzyme encoded by the recent discovered Vkorc1 gene (Li 
et al, 2004; Rost et al, 2004). This enzyme catalyzes the vitamin K 2,3-epoxide reductase activity. This enzymatic activity is essential for recycling vitamin $\mathrm{K}$. The function of VKORC1 is to regenerate vitamin $\mathrm{K}$ and vitamin $\mathrm{K}$ hydroquinone ( $\mathrm{K}$ and $\mathrm{KH} 2$ ) from vitamin $\mathrm{K}$ 2,3-epoxide ( $\mathrm{K}>\mathrm{O}$ ), a byproduct of the vitamin $\mathrm{K}$-dependent gamma carboxylation reaction (Oldenburg et al, 2008). Inhibition of VKORC1 by 4-hydroxycoumarin derivatives limits the amount of $\mathrm{KH} 2$ available for the carboxylation reaction and results in partially carboxylated vitamin K-dependent blood clotting factors II, VII, IX, X. The specific inhibition of VKORC1 results in a stop of the clotting factors activation leading to a delayed death by hemorrhage. The inhibiting effect of ferulenol on VKORC1 was shown in rat (Gebauer et al,), but not on VKORC1 of species exposed to $F$. communis L..

Previous studies in sheep treated with ferulenol indicated a sharp decreased in activity for several coagulation factors (Tligui et al, 1994). This observation seems to be coherent with the VKORC1-mediated antivitamin K properties of 4-oxygenated coumarins. Nevertheless, another mechanism leading to decrease in coagulation factors was proposed. This decrease was proposed to be due to an impairment of coagulation factors biosynthesis induced by a cytotoxic effect of ferulenol (Monti et al, 2007). Moreover, the toxicity of $F$. communis L. was reported to be not correlated with its contents in ferulenol (Appendino et al, 1988) and another prenylated coumarin, the pyranoferprenin, isolated from $F$. communis L., showed in vivo haemorrhagic activity (Appendino et al, 1988). Nevertheless, the inhibiting effect of ferprenin on VKORC1 was never demonstrated. This study aims to compare the inhibiting effect of ferulenol and ferprenin on VKORC1 from different species in order to demonstrate the mode of action of phytochemicals presumed to be responsible for the toxicity of $F$. communis, plant associated to intoxication that has considerable importance in plant/animal interactions in the Mediterranean countries. 


\section{RESULTS}

2.1.Determination of vitamin $K$ epoxide reductase activity in liver of animal species susceptible to be exposed to $F$. communis $\mathrm{L}$.

In order to evaluate the vitamin $\mathrm{K}$ recycling ability of animal species exposed to $F$. communis L., liver microsomes were prepared from cow, calf, goat, lamb, pig, boar and horse. VKOR activity was thus measured at saturating concentration of vitamin $\mathrm{K}$ epoxide substrate (i.e., $200 \mu \mathrm{M})$ from the various microsomal fractions. Figure 2 presents the results obtained. All the liver microsomal fractions tested in this study were able to reduce vitamin $\mathrm{K}$ epoxide in vitamin K. VKOR activities were found statistically different between species (VKOR activities determined from horse and boar were excluded of the one way analysis of variance). VKOR activity measured in cow liver microsomes was 1.5 to 2-fold higher than that measured in goat, lamb and pig liver.

\subsection{Determination of the inhibiting effect of ferulenol and ferprenin on vitamin $K$ epoxide reductase activity}

In order to analyze the efficiency of ferulenol and ferprenin as inhibitor of the VKOR activity, susceptibilities to ferulenol and ferprenin were first determined in the presence of calf liver microsomes. The plots of the velocity of the VKOR activity catalysed by calf liver microsomes, versus the substrate concentration in the presence of different concentrations of ferulenol or ferprenin are presented in Figure 3A and 3B, respectively. The inhibiting effects 
of ferulenol and ferprenin on VKOR activity catalysed by calf liver microsomes were compared with that obtained in the same conditions with warfarin (Figure 3C). Ferulenol was able to inhibit VKOR activity. The addition of ferulenol did not modify the apparent $\mathrm{K}_{\mathrm{m}}(40.3 \pm 5 \mu \mathrm{M})$, while it decreased the apparent $\mathrm{V}_{\max }$ (Figure 3A). Ferulenol is thus able to inhibit VKOR activity catalysed by calf liver microsomes in a non-competitive manner, as observed with warfarin (Figure 3C). Data were fitted to the Michaelis-Menten model, which takes into account the presence of either competitive, non-competitive, or uncompetitive inhibitor by non-linear regression. A fit was possible when the model that takes into account a non-competitive inhibitor was used only. Finally, $\mathrm{K}_{\mathrm{i}}$ towards ferulenol for calf liver microsomes was $0.076 \pm 0.007 \mu \mathrm{M}$. $\mathrm{K}_{\mathrm{i}}$ towards warfarin obtained in the same conditions was $0.51 \pm 0.04 \mu \mathrm{M}$.

Ferprenin was also able to inhibit the VKOR activity catalyzed by calf liver microsomes, but with concentration much higher than those used for inhibition of VKOR activity by ferulenol (Figure 3B). Ferprenin inhibited the VKOR activity in a non-competitive manner, as described for ferulenol. $\mathrm{K}_{\mathrm{i}}$ towards ferprenin for calf liver microsomes was $8.2 \pm 0.05 \mu \mathrm{M}$. VKOR activity in calf liver microsomes was thus 100 -fold more resistant to the action of ferprenin than ferulenol.

\subsection{Determination of the species variability of the VKORC1-inhibiting effect of} ferulenol

In order to analyse the variation of the efficiency of ferulenol as inhibitor of VKOR activity in the animals exposed to $F$. communis $L ., \mathrm{K}_{\mathrm{i}}$ values for ferulenol were determined in liver microsomal fractions from cow, goat, lamb, pig, horse and boar and compared to $\mathrm{K}_{\mathrm{i}}$ obtained for rat liver microsomes. Ferulenol inhibited the VKOR activity in a non-competitive manner for all the microsomal fractions we analysed (data not shown). The $\mathrm{K}_{\mathrm{i}}$ values for ferulenol are 
in Table 1 . They were found statistically different between species $\left(\mathrm{K}_{\mathrm{i}}\right.$ determined from-horse and boar were excluded of the one way analysis of variance). $K_{i}$ for ferulenol determined in cow liver microsomes was 3- to 3.8-fold higher than that measured in calf, goat, lamb, pig and rat liver.

\subsection{Determination of the species variability of the VKORC1-inhibiting effect of ferprenin}

In order to analyse the variation of the efficiency of ferprenin as inhibitor of VKOR activity in the animals exposed to $F$. communis $L$., $\mathrm{K}_{\mathrm{i}}$ values towards ferprenin were determined in liver microsomal fractions from cow, goat, lamb, pig, horse and boar and compared to $\mathrm{K}_{\mathrm{i}}$ obtained for rat liver microsomes. Ferprenin inhibited the VKOR activity in a non-competitive manner for all the microsomal fractions we analysed (data not shown). The $K_{i}$ values for ferprenin are in Table 1 . They were found statistically different between species $\left(\mathrm{K}_{\mathrm{i}}\right.$ determined from horse and boar were excluded of the one way analysis of variance). $K_{i}$ for ferprenin determined in cow liver microsomes was 3.2-, 6.0-, 2.1-, 1.6- and 9.0-fold higher than that measured in calf goat, lamb, pig and rat liver.

\subsection{Determination of the species variability of the VKORC1-inhibiting effect of warfarin}

In order to compare the efficiency of ferulenol and ferprenin as inhibitor of VKOR activity to that of warfarin, $\mathrm{K}_{\mathrm{i}}$ for warfarin were determined in liver microsomal fractions from cow, goat, lamb, pig, horse and boar. The $\mathrm{K}_{\mathrm{i}}$ values are in Table 1 . They were found statistically different between species $\left(\mathrm{K}_{\mathrm{i}}\right.$ determined in horse and boar were excluded of the one way analysis of variance). 


\section{DISCUSSION}

Ferulenol and ferprenin are 4-oxygenated coumarin derivatives synthesized by $F$. communis L.. Coumarin derivatives are known to be potential inhibitor of vitamin $\mathrm{K}$ epoxide reductase activity responsible for the recycling of vitamin $\mathrm{K}$, a cofactor essential for the coagulation process. The presence of ferulenol and/or ferprenin was therefore associated with the toxicity of the 'poisonous' chemotype of $F$. communis L. (Appendino et al, 1988; Fraigui et al, 2001). Indeed, the symptomatology associated with $F$. communis $L$. poisoning is coherent with an anti-VKORC1 activity of ferulenol and/or ferprenin. Nevertheless, few studies allowing to prove the role of ferulenol and/or ferprenin in 'ferulosis' are available. The involvement of ferulenol in the hemorrhagic syndrome was shown by in vivo studies in rats (Aragno et al, 1988, Fraigui et al, 2001, Fraigui et al, 2002, Lamnaouer et al, 1991; Tagliapietra et al, 1989), mice (Fraigui et al, 2001, Fraigui et al, 2002), sheep (Lamnaouer et al, 1990; Otieno et al, 1979; Shlosberg et al, 1985) and lamb (Egber et al, 1998). Nevertheless, the mechanism was not described, except that consumption of ferulenol was associated to decrease in vitamin Kdependent clotting factors. The unique study demonstrating the in vitro inhibiting effect of ferulenol on VKORC1 was performed in rat (Gebauer, 2007), while inter-species differences might exist, since the replacement of one single amino-acid of VKORC1 can lead to enzyme resistant to coumarin derivatives (Grandemange et al, 2010, Hodroge, 2011). The inhibiting effect of ferulenol on VKORC1 of farm animals is still unknown.

In order to determine the underlying mechanism of 'ferulosis', VKOR activity was first analyzed in animal species exposed to $F$. communis $L$. VKOR activity has been well characterized in rodents because of the intensive use of coumarin derivatives as rodenticides. In rodents, this activity is exclusively catalyzed by VKORC1 in liver, while this activity might be catalyzed by two enzymes, VKORC1 and VKORC1L1, in other tissues. In farm 
animals, VKOR activity was until now never studied. Liver microsomes from cow, calf, goat, lamb, pig, boar and horse were used to examine VKOR activity by a DTT-driven VKOR assay, as previously described (Hodroge et al, 2011). This experimental method is a direct approach based on the measurement of the VKORC1 reaction product, the vitamin $\mathrm{K}$. By using this method, VKOR activity was detected in liver of all species analyzed in this study. Nevertheless, variations of VKOR activity between species were observed. VKOR activity measured in cattle liver was 1.5 - to 2 -fold higher than in other species, suggesting interspecies variation in the vitamin $\mathrm{K}$ recycling ability. VKOR activity measured in the liver of the different species was efficiently inhibited by warfarin with $\mathrm{Ki}$ about 1 to $2 \mu \mathrm{M}$, as observed for rats. The inhibition of VKOR activity by warfarin observed in this study is thus totally coherent with an exclusive involvement of VKORC1 in hepatic VKOR activity of the different species exposed to F. communis L., as described for rats (Hammed et al, 2013).

Since VKOR activity was detected in liver of all animals used in this study, effect of ferulenol and ferprenin on this VKOR activity was analyzed. Ferulenol and ferprenin were found in this study to be able to inhibit VKOR activity in a non-competitive manner, as described for warfarin. The mechanism of inhibition proposed by Silverman (1980) implies the acylation by the 4-oxygenated coumarins of one Cys of the catalytic site of VKORC1 or possibly of a nearby nucleophile amino acid. The proposed mechanism agrees with the irreversible characteristic of the inhibition of the VKOR activity by ferulenol and ferprenin observed in this study.

Ferulenol was already reported to inhibit rat VKORC1, with Ki of $0.098 \mu \mathrm{M}$ (Gebauer, 2007). In this study, inhibition of rat VKORC1 by ferulenol was highly similar to that previously reported, with a Ki of $0.04 \mu \mathrm{M}$. Ki obtained for ferulenol is 10 -fold lesser than that obtained for warfarin (Figure 4). Ferulenol is thus a more potent inhibitor of VKOR activity than 
warfarin, which is traditionally used in human medicine for patients requiring anticoagulation therapy. Ki obtained for ferulenol is similar to those obtained for the most powerful molecules used as rodenticides such as difethialone or brodifacoum (Hodroge et al, 2011). Ferulenol is also able to inhibit VKORC1 of other species, with Ki similar to that obtained for rat, despite the variations of VKORC1 amino acid sequences between species (i.e., identities between VKORC1 amino acid sequences are comprised between 68 and 84\%) (Figure 5). Surprisingly, VKORC1 of cow seems to be more resistant to ferulenol than other VKORC1, while it presents the highest amino acid sequence identity with rat VKORC1. Nevertheless, susceptibility to ferulenol can be qualified to be similar between rat and farm animals. This result is coherent with published studies showing that repeated administration of ferulenol was able to lead to increase in prothrombin time and in reduction of pool of vitamin Kdependent clotting factors (Aragno et al, 1988, Fraigui et al, 2001; Shlosberg et al, 1985; Tagliapietra et al, 1989).

When ferprenin was orally given to rats, Aragno et al (1988) indicates that this compound clearly increases prothrombin time at very high dosage (a minimum of $30 \mathrm{mg} \cdot \mathrm{kg}^{-1}$ for 3 days or $10 \mathrm{mg} \cdot \mathrm{kg}^{-1}$ for 5 days). Using DTT-driven VKOR assay, ferprenin was also found to be able to inhibit VKOR activity in liver of all species analyzed in this study. Contrary to ferulenol, this ability to inhibit VKOR activity is very surprising, because a free 4hydroxycoumarin moiety was described to be necessary for anti-VKORC1 activity. Nevertheless, Ki obtained for ferprenin were 2 to 10 -fold higher than those obtained for warfarin (Figure 4) and ferulenol is 100 - to 500 -fold more potent to inhibit VKOR activity than ferprenin, according to the species (Figure 4). Ferprenin is thus a very bad inhibitor of VKOR activity for all species analyzed in this study. The direct effect of this molecule remains surprising because the 4-OH moiety of the coumarinic ring appears to be essential for 
the interaction with VKORC1 enzyme as shown by Gebauer (2007). The hydrolysis of the

\section{CONCLUSIONS}

Ferulenol, and in a lesser extent, ferprenin are thus certainly both responsible for the hemorrhagic syndrome. Neverteheless, $F$. communis also contain COX-inhibiting polyacetylenes that could synergistically contribute to the poisonous property of the plant (Appendino et al, 1993). Toxicity of ferulenol and ferprenin is also driven by pharmacokinetics and inter-species variations in pharmacokinetics of these compounds. Few studies about pharmacokinetics of these compounds are available. Published results argue for a high metabolic clearance of ferulenol. Indeed, while Ki obtained for ferulenol is lower than that obtained for warfarin, the dosage of ferulenol necessary to lead to an increase in prothrombin time in rat appears to be about 10-fold higher than that used for warfarin (Aragno et al, 1988). The hemorrhagic effect is strictly dependent on the continuous presence of high concentration of VKORC1 inhibitor in the liver. Indeed, few hours without this inhibition will be enough to fully restore the pool of clotting factors. Considering a high metabolic clearance, the toxicity of such compounds will directly depend on the pattern of administration. Frequent repeated dosages are strictly necessary to maintain the inhibiting concentration in the liver. Ruminal administration can be considered as a continuous delivery of ferulenol even if the 
consumption of $F$. communis L. is not continuous as observed in sheep after oral administration of repeated administration of ferulenol. (Tligui et al, 1994). The detection of ferulenol in 'non-poisonous' chemotypes of $F$. communis L. (Rubiolo et al, 2006) questioned the only responsibility of ferulenol and ferprenin in the hemorrhagic syndrome. Nevertheless, ferulenol and ferprenin are found to be present in far smaller amounts in 'non-poisonous' chemotypes of $F$. communis L. than in 'poisonous' chemotypes. The consumption of these chemotypes does not allow to reach sufficient hepatic concentration leading to complete inhibition of VKOR activity in liver and thus in a stop of the vitamin K-dependent clotting factors activation.

\section{MATERIALS AND METHODS}

\subsection{Animals}

Livers from lamb, cow, horse, goat, pig and calf were collected from the slaughterhouse at Saint Romain de Popey (France) under special authorization of the veterinary services and after veterinary health examination. Male OFA-Sprague Dawley rats (200g) were obtained from a commercial breeder (Charles River, L'Arbresles, France) and acclimated for a minimal period of 5 days. Rat food and water were available ad libitum. The rats were killed by decapitation. The boar was hunted and the liver was removed according to the regulations. All samples were immediately frozen at $-80^{\circ} \mathrm{C}$. Three different animals of each species were sampled excepted in horse and boar where only one sample could be obtained.

\subsection{Chemical syntheses}

Vitamin K1 (Phylloquinone) was converted into vitamin K1OX according to Tishler et al (1940). Ferulenol was synthesized accordingly to Gebauer et al (2007). Oxidation of 
trans,trans-farnesol with PDC afforded farnesal in $87 \%$ yield (Hu et al, 2004). Ferprenin was obtained by reaction of 4-hydroxycoumarin with 2 equivalents of trans,trans-farnesal in water at $80^{\circ} \mathrm{C}$, in a Knoevenagel / electrocyclization tandem mechanism (Jung et al, 2010) (SI 1).

\subsection{Microsomes preparation}

Liver microsomes were prepared by differential centrifugations as previously described (Moroni et al, 1995). Protein concentrations were determined by the method of Bradford (1976) using serum albumin as a standard.

\subsection{Vitamin $\mathrm{K}$ epoxide reductase activity}

Microsomal vitamin $\mathrm{K}$ epoxide reductase (VKOR) activity was assayed according to a modified protocol previously described by Thijssen (1987), Thijssen and Baars (1989) and Misenheimer and Suttie (1990). Briefly, standard reactions were performed in $200 \mathrm{mM}$ Hepes buffer $(\mathrm{pH} 7.4)$ containing $150 \mathrm{mM} \mathrm{KCl}, 1 \mathrm{mM}$ dithiothreitol, $1 \mathrm{mg}$ of total proteins. The reaction was started by the addition of vitaminK $>0$ solution in $1 \%$ Triton $\mathrm{X}-100$. After incubation at $37^{\circ} \mathrm{C}$ for $30 \mathrm{~min}$, the reaction was stopped by adding $4 \mathrm{~mL}$ of iced 1:1 isopropanol/hexane solution. After centrifugation at $5000 \mathrm{~g}$ for $10 \mathrm{~min}$, the hexane layer was removed and dried under nitrogen. The dry residue was immediately dissolved in $0.2 \mathrm{~mL}$ of isopropanol and reaction product was analyzed by UV-HPLC.

\subsection{Vitamin K1 measurement}

Vitamin K1 was measured by high performance liquid chromatography (HPLC). The HPLC chain consisted of an autosampler (Merck AS-2000A), an intelligent pump (Merck L-6200A), a UV-VIS detector (Merck L-4250) and an enregistror (Merck SS420X). Separation was achieved on a C8, $5 \mu \mathrm{m}, 4,6 \times 150 \mathrm{~mm}$ analytical column (Sunfire, Irl). The flow rate of the 
mobile phase (methanol $96 \%$, water $4 \%$, formic acid $1 \%$ ) was $0.8 \mathrm{~mL} / \mathrm{min}$. The column temperature was $40^{\circ} \mathrm{C}$. Detection was performed at $248 \mathrm{~nm}$.

\subsection{Kinetics}

Kinetic parameters $\left(\mathrm{K}_{\mathrm{m}}\right.$ and $\left.\mathrm{V}_{\max }\right)$ were obtained from at least two separate experiments after the addition of increasing amounts of vitamin $\mathrm{K}>\mathrm{O}(0.003$ to $0.2 \mathrm{mM})$ to the standard reaction. The estimation of the kinetic parameters was achieved by the incubation of at least 9 different concentrations of vitamin $\mathrm{K}>\mathrm{O}$. Incubations were performed in duplicate. Data were fitted by nonlinear regression to the Michaelis-Menten model using the curve fitter program of Sigmaplot $9.0^{\mathrm{TM}}$ software.

In order to evaluate the inhibiting effect of various molecules (warfarin, ferulenol and ferprenin) (figure 1) on VKOR activity, inhibition parameters $\left(\mathrm{K}_{\mathrm{i}}\right)$ were determined after addition of various concentrations of molecules to the standard reaction. Inhibition parameters were first assessed with 4 different concentrations $(0.01,1,10$ and $30 \mu \mathrm{M})$ and further more precisely determined using concentrations from about 0.05 to $20 \times \mathrm{K}_{\mathrm{i}}$. Data were fitted by nonlinear regression to the non-competitive inhibition model using Sigmaplot $9.0^{\mathrm{TM}}$ software.

\section{ACKNOWLEDGEMENTS}

This work was supported by grants ISI nI1301001W “NEORAMUS” from Bpi France.

\section{LEGENDS OF FIGURES}

Figure 1: Chemical structures of warfarin (A), Ferulenol (B) and Ferprenin (C)

Figure 2 : Vitamin K epoxide reductase activity in animals exposed to $F$. communis. L. Enzyme activity was evaluated in the presence of $200 \mu \mathrm{M}$ of KOX and $1 \mathrm{mg}$ of liver 
microsomal proteins. Each data point represents the mean \pm SD of three individual determinations.

Figure 3 : Plots of vitamin K epoxide reductase activity versus vitamin K > O (6.25-200 lM), in the presence of various concentrations of ferulenol (A) or ferprenin (B) or warfarin (C) incubated with calf liver microsomes.

Figure 4 : Comparison of the inhibition effect of warfarin, ferulenol and ferprenin using various liver microsomes. A/ Inhibition effect of ferulenol or ferprenin compared to warfarin, B/ Inhibition effect of Ferulenol compared to ferprenin.

Figure 5 : Multiple sequence alignment of VKORC1 enzymes of animals exposed to $F$. communis $\mathrm{L}$. The active site is indicated by the box.

SI 1 : Ferprenin synthesis 


\section{REFERENCES}

Appendino, G., Tagliapietra, S., Gariboldi, P., Nano, G.M., Picci, V., 1987. $\omega$-Oxygenated prenylated coumarin from Ferula communis. Phytochemistry. 27, 3619-3624.

Appendino, G., Tagliapietra, S., Nano, G.M., Picci, V., 1988. Ferprenin, a prenylated coumarin from Ferula communis. Phytochemistry. 27, 944-946.

Appendino, G., Tagliapietra, S., Nano, G.M., Picci, V., 1993. An Antiplatelet Acetylene from the Leaves of Ferula communis. Fitoterapia. 64, 179.

Appendino, G., Cravotto, G.C., Sterner, O., Ballero, M., 2001. Oxygenated sesquiterpenoids from a non poisonous sardinian chemotype of giant fennel (Ferula communis). J. Nat. Prod. 64, 393-395.

Aragno, M., Tagliapietra, S., Nano, G.M., Ugazio, G., 1988. Experimental studies on the toxicity of Ferula communis in the rat. Res. Commun. Chem. Pathol. Pharmacol. 59, 399-402.

Arnoldi, L., Ballero, M., Fuzzati, N., Maxia, A., Mercalli, E., Pagni, L., 2004. HPLC-DADMS identification of bioactive secondary metabolites from Ferula communis roots. Fitoterapia. 75, 342-354.

Benkhalti, F., Lamnaouer, D., 1994. Activité anticoagulante de quelques principes isolés de Ferula communis L. Actes du $1^{\mathrm{er}}$ colloque international « La pharmacopée Arabo-islamique, Hier et Aujourd'hui ». 215-220. 
Bradford, M.M., 1976. A rapid and sensitive method for the quantitation of microgram quantities of proteins utilizing the principle of protein dye binding. Nature. 227, 248-254.

Carboni, S., Malaguzi, V., Marsili, A., 1964. Ferulenol, a new coumarin derivative from Ferula communis. Tetrahedron Lett. 38, 2783-2786.

Cauwet-Marc, A.M., 1990. Le férulisme. Rev. Res. Amélior. Agr. Milieu Aride. 2, 1-7.

Cauwet-Marc, A.M., 1981. Le complexe Ferula communis L. dans ses populations du sud de la France et de la Corse. Biologie Ecologie Méditerranéenne. 8, 101-118.

Cauwet-Marc, A.M., 1981. Le genre Ferula communis L. sur le pourtour du bassin méditerranéen. $106^{\text {ème }}$ congrès des Sociétés savantes, Perpignan. 22, 77-87.

Cornevin, C., 1887. Des plantes vénéneuses et des empoisonnements qu'elles déterminent. Librairie de Firmin-Didot et Cie, Paris, France, pp. 380-396.

Egber, A., Perevolotsky, A., Yonatan, R., Shlosberg, A., Belaich, M., Landau, S., 1998. Creating aversion to giant fennel (Ferula communis) in weaned orphaned lambs. Applied Animal Behaviour Science. 61, 51-62.

Fraigui, O., Lamnaouer, D., Faouzi, M.Y., 2001. Acute toxicity of ferulenol, a 4hydroxycoumarin isolated from Ferula communis L. Vet. Hum. Toxicol. 44, 5-7. 
Gault, G., Riera, M., Berny, P., Benoit, E. and Grancher, D., 2015. Giant fennel (Ferula communis L.) intoxications in livestock in France. Proceedings of the $9^{\text {th }}$ Congress of the International Society of Poisonous plants (ISOPP). Hohhot (PR China). 15, 95-99.

Gebauer, M., 2007. Synthesis and structure-activity relationships of novel warfarin derivatives. Bioorg. Med. Chem. 15, 2414-2420

Grandemange, A., Lasseur, R., Longin-Sauvageon, C., Benoit, E. and Berny, P., 2010. Distribution of VKORC1 single nucleotid polymorphism in wild Rattus norvegicus in France. Pest. Manag. Sci. 66, 270-276.

Hammed, A., Matagrin, B., Spohn, G., Prouillac, C., Benoit, E., Lattard, V., 2013. VKORC1L1, an enzyme rescuing the VKOR activity in some extrahepatic tissues during anticoagulation therapy. J Biol Chem. 288, 28733-28742.

Hodroge, A., Longin-Sauvageon, C., Fourel., I., Benoit, E., Lattard, V., 2011 Biochemical characterization of spontaneous mutants of rat VKORC1 involved in the resistance to antivitamin K anticoagulants. Arch. Biochem. Biophys. 515,14-20.

Hu, H., Harrison, T.J., Wilson, P.D., 2004. A modular and concise total synthesis of ( \pm )Daurichromenic acid and analogues. J. Org. Chem. 69, 3782-3786.

Infante, M., 1965. Intoxicacion por Ferula communis L. (intoxication by Ferula communis L.). Archivos de zootecnia. 14, 25-54. 
Jung, E.J., Park, B.H., Lee, Y. R., 2010. Environmentally benign, one-pot synthesis of pyrans by domino Knoevenagel / $6 \pi$-electrocyclization in water and application to natural products. Green Chem. 12, 2003-2011.

Lamnaouer, D., Fraigui, O. and Abadome, F., 1991. Toxicité et activité anticoagulante de quelques constituants de Ferula communis L. chez le rat. Al Biruniya, Revue Marocaine de Pharmacie, Rabat. 7, 135-142.

Lamnaouer, D., Omari, M., Mounir, A., El-Alouani, M., 1990. Activité anticoagulante de Ferula communis L. chez le mouton. Maghreb Vétérinaire. 5, 5-10.

Lannehoa, Y., Harry, P., Michau, C., Fareta, A. and Merad, R., 1998. Anal bleeding due to hypovitamin K caused by ingesting « fassoukh ». Presse médicale, 31, 1579.

Li, T., Chang, C.Y., Jin, D.Y., Lin, P.J., Khvorova. A., Stafford, D.W., 2004. Identification of the gene for vitamin K epoxide reductase. Nature. 427, 541-544.

Misenheimer, T.M., Suttie, J.W., 1990. Warfarin resistance in a chicago strain of rats. Biochem. Pharmacol. 40, 2079-2084.

Miski, M., Mabry, T., 1985. Daucane esters from ferula communis subsp. Communis. Phytochemistry. 24, 1735-1741. 
Monti, M., Pinotti, M., Appendino, G., Dallocchio, F., Bellini, T., Antognoni, F., Poli, F., Bernardi, F., 2007. Characterization of anti-coagulant properties of prenylated coumarin ferulenol. Biochem. Biophys. Acta. 1770, 1437-1440.

Moroni. C., Longin-Sauvageon. C., Benoit. E., 1995. The Flavin-containing monooxygenase in rat liver : evidence for the expression of a second form different from FMO1. Biochem. Biophys. Res. Commun. 212, 820-826.

Oldenburg, J., Marinova, M., Müller-Reible, C., Watzka, M., 2008. The vitamin K cycle. Vitam. Horm. 78, 35-62.

Otieno, P., 1979. Toxicity of Ferula Communis in sheep and goats. Annual report of the scientific research division of the Kenya Ministry of Agriculture in 1975. 23-24.

Rost, S., Fregin, A., Ivaskevicius, V., Conzelmann, E., Hörtnagel, K., Pelz, H.J., Lappegard, K., Seifried, E., Scharrer, I., Tuddenham, E.G., Müller, C.R., Strom, T.M., Oldenburg, J., 2004. Mutations in VKORC1 cause warfarin resistance and multiple coagulation factor deficiency type 2. Nature. 427, 537-541.

Rubiolo, P., Matteodo, M., Riccio, G., Ballero, M., Christen, P., Fleury-Souverain, S., Veuthey J.L., Bicchi, C., 2006. Analytical discrimination of poisonous and nonpoisonous chemotypes of giant fennel (Ferula communis L.) through their biologically active and volatile fractions. J. Agric. Food Chem. 54, 7556-7563. 
Sacchetti, G., Appendino, G., Ballero, M., Loy, C., Poli, F., 2003. Vittae fluorescence as a tool to differentiate between poisonous and non poisonous populations of giant fennel (Ferula communis) of the island Sardinia (Italy). Biochem. Syst. Ecol. 31, 527-534.

Shlosberg, A. and Egyed, M.N., 1985. Experimental Ferula communis (giant fennel) toxicosis in sheep. Zentralblatt für Veterinämedizin Reihe A. 32, 778-784.

Silverman, R.B., 1980. A Model for a "Molecular Mechanism of Anticoagulant Activity of 3Substituted-4-Hydroxycoumarins. J. Am. Chem. Soc.102, 5421-5423.

Tagliapietra, S., Aragno, M., Ugazio, G., Nano, G.M., 1989. Experimental studies on the toxicity of some compounds isolated from Ferula communis in the rat. Res. Commun. Chem. Pathol. Pharmacol. 66, 333-336.

Thijssen, H., 1987. Vitamin $\mathrm{K}$ epoxide reductase of Scottish resistance genes is not irreversibly blocked by warfarin. Biochem. Pharmacol. 36, 2753-2757.

Thijssen, H., Baars, L., 1989. Microsomal warfarin binding and vitamin K 2,3-epoxide reductase. Biochem. Pharmacol. 38, 1115-1120.

Tishler, M., Fieser, L., Wendler, N., 1940. Hydro, oxydo and other derivatives of vitamin K1 related compounds. J. Am. Chem. Soc. 62, 2866-2871. 
Tligui, N., Ruth, G.R., Felice L.J., 1994. Plasma ferulenol concentration and activity of clotting factors in sheep with Ferula communis variety brevifolia intoxication. Am. J. Vet. Res. 55, 1564-1569.

Valle, M.G., Appendino, G., Nano, G.M., Picci, V., 1987. Prenylated coumarin and sesquiterpenoids from Ferula communis. Phytochemistry. 26, 253-256. 
Table $1: K_{\mathrm{i}}$ values of ferulenol, ferprenin and warfarin determined in various liver microsomes.

\begin{tabular}{|c|c|c|c|}
\hline Species & $\begin{array}{c}\text { Ki for Ferulenol } \\
(\boldsymbol{\mu M})\end{array}$ & $\begin{array}{c}\text { Ki for Ferprenin } \\
(\boldsymbol{\mu M})\end{array}$ & $\begin{array}{c}\text { Ki for Warfarin } \\
(\boldsymbol{\mu M})\end{array}$ \\
\hline Cow & $0.13 \pm 0.06$ & $16.6 \pm 1.2$ & $2.3 \pm 0.4$ \\
\hline Calf & $0.04 \pm 0.01$ & $5.2 \pm 1.4$ & $2.5 \pm 0.1$ \\
\hline Goat & $0.04 \pm 0.02$ & $2.8 \pm 1.4$ & $1.6 \pm 1.3$ \\
\hline Lamb & $0.03 \pm 0.01$ & $8.0 \pm 4.0$ & $0.8 \pm 0.2$ \\
\hline Pig & $0.04 \pm 0.01$ & $10.3 \pm 1.9$ & $1.2 \pm 0.2$ \\
\hline Boar & $0.08 \pm 0.02$ & $3.7 \pm 0.6$ & $0.8 \pm 0.1$ \\
\hline Horse & $0.04 \pm 0.01$ & $16.3 \pm 2.1$ & $1.3 \pm 0.3$ \\
\hline Rat & $0.03 \pm 0.01$ & $1.9 \pm 0.4$ & $0.5 \pm 0.1$ \\
\hline
\end{tabular}


Figure

Click here to download high resolution image

A/

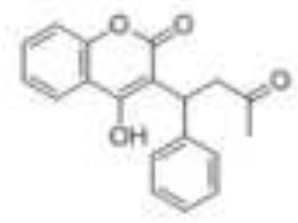

B/

Cl
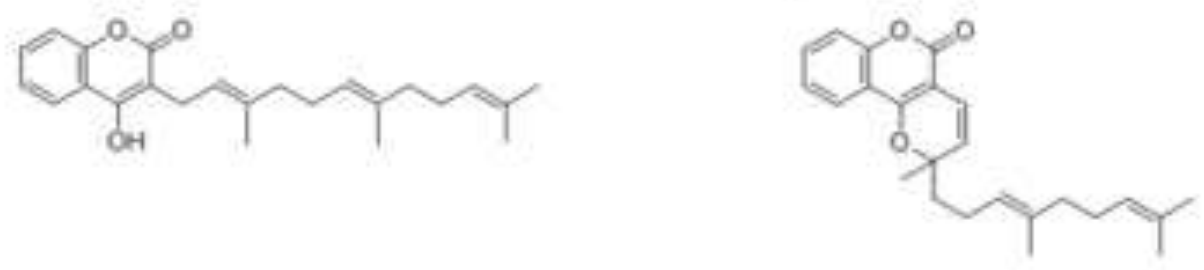

Figure 1 
Click here to download high resolution image

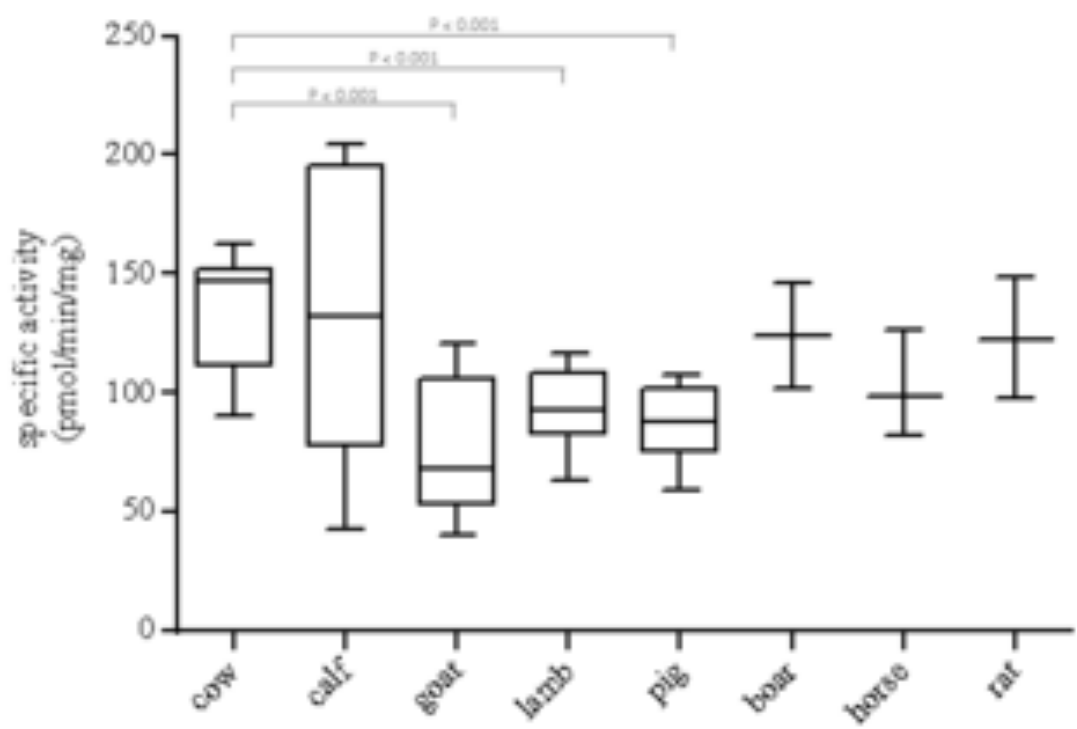

Figure 2 
Click here to download high resolution image

A/

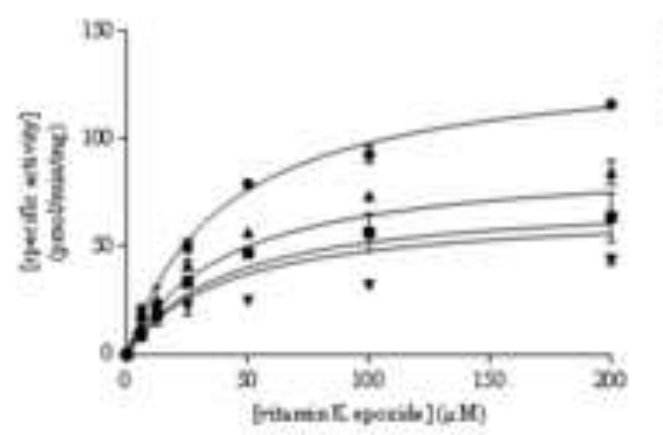

B/

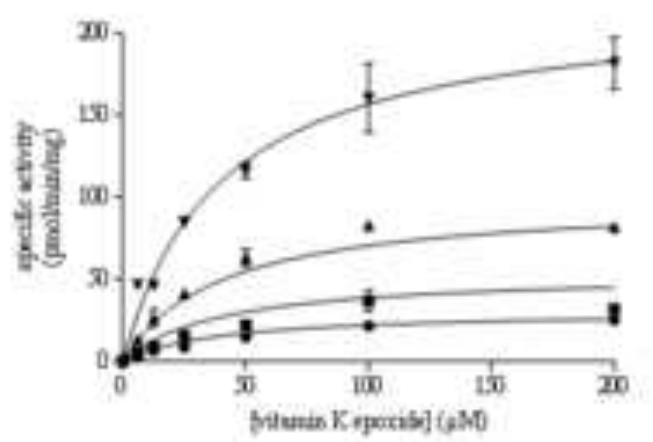

- forpmias 50 pM

- ferpmin 25 jM

- firminatop

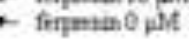

B)

\section{c/}

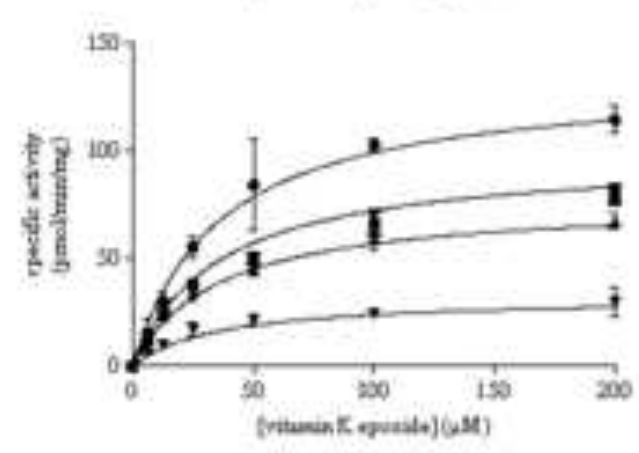

- toufonde

- varfon

- wartia

a vers $350 \mathrm{~N}$

Figure 3

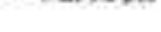


Click here to download high resolution image
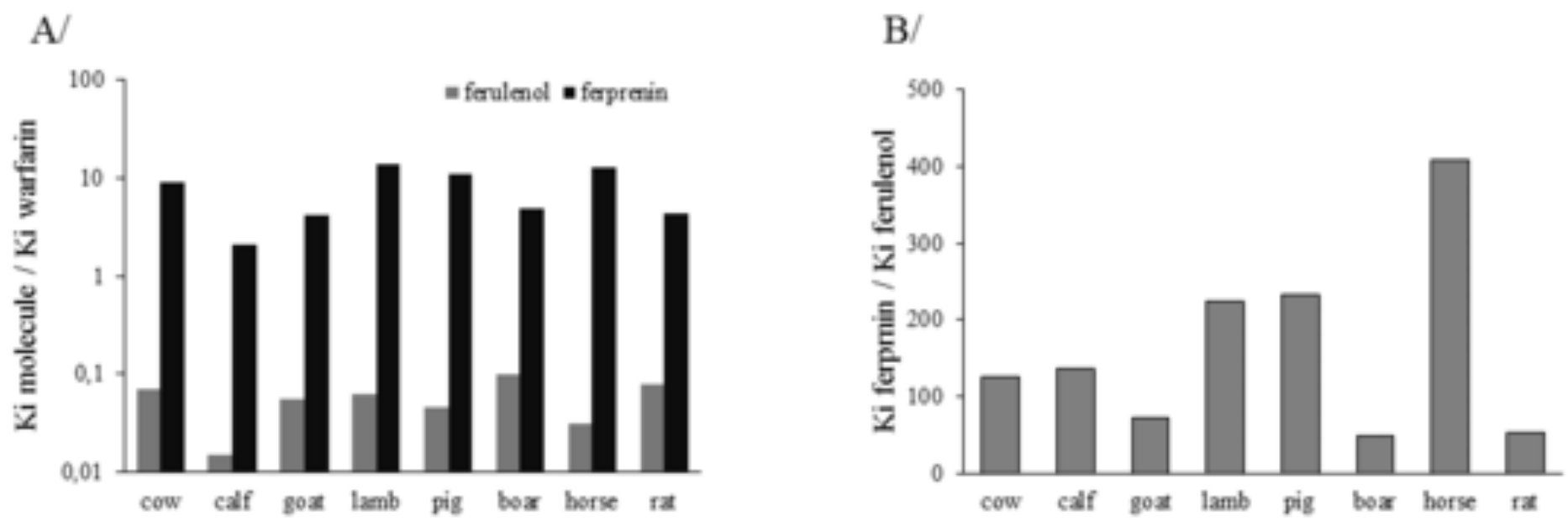

Figure 4 
Rathus nonogicut WOAC: MGTTWRSPGB ERLALCLAGL MLSLYALHVK AARARNEDYR ALCDVGTAIS CSRVFSSRWG 60 Bos tauna WKORC1 MGETTWRSPGW VRLALCLAGL VLSLYALHVK AARARDRDYR ALCDVGTAIS CSRVFSSRWG 60

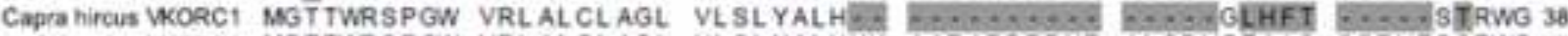
OVis aries WORC1 MGTTWRSPGW VRLALCLAGL VLSLYALHVK AARARORDYR ALCDVGTAIS CSRVFSSRWG BO

Equus caballut WKOAC: MGASWRSPOW VRLALCLAGL MLSL YALHVK AARARDKOYR ALCOVGTAIS CSRVFSSRWG SO SUs scrob WORCT MOTTWRNPGW VRFALCLAGL VLSLYALHVK AARARDRWYR ALCDVOTAIS CSRVFSSRWG SO

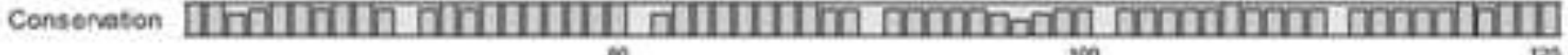
in $\$ 60$

Ratus nonwicus WORC: RGFGLVEHVL GGOSYLNOSN SIFGCMFYTI QLLLGCLRGR WASTLLIILSS LVSYAGSEYL 120 Bos taurs WORC: RGFGLVEHVL GKDSILNOSN SIFGCIFYTL QLLLGCLOGR WASVLLRLSC LVSLAGSVYL 120 Capra hircus WKOACI RGFGL VEHVL GKDSVLNOSN SIFGCIFYTL OLLLGCLOGR WYSVLLRLSS LVSLAGSVYL 98 OMis aries WORC1 RGFGLVEHVL GKDSYLNOSN SIFGCIFYTL OLLLGCLOGR RVSYLLRLSS LVSLAGSVYL 120

Equis caballun WORC1 RGFGLVEHVL GRDS LNOSN SIFGCIFYTL QLLLGCLOGR WASTLLELSS LVSLAGSLYL 120 Sus scruta WORC: GGFOLVEGVL GKDSNLNOSN SIFGCIFYTL OLLLGCLRGR WASVLLYLSS LVSLAGSVYL 120

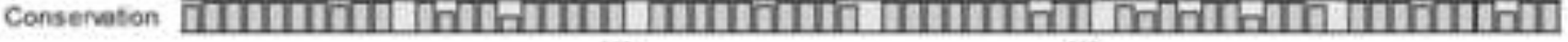
160 160

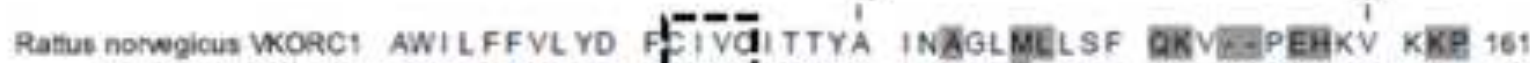
Bos auns WORC: AWILFFVLYD F. IVdITTYA INVGL IVLSF REVOGPQGKV KGH 163 Caprahircus WKORC1. AWI LFFVL YD FIVdITTYA INVGL TVLSF REVOGSOOKV KGH 141 OVI aries WORC1 AWILFFVL YD FFIVGITTYA INVGL TVLSF REVOGPODKV KGH 153 Equus caballut WORCI AWILFFVL YO FEIVGITTYA INVGLMILSF REVOGPOGKV $\ldots 160$ Sus scrota KORCI AWILFFVL YD FEIVG ITTYA INEGLUVLSF REMOGPCSKV KEH 163

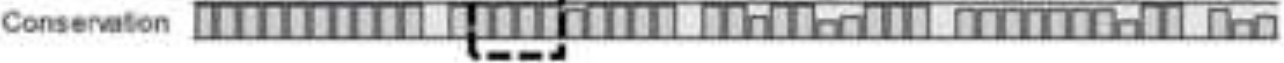

Figure 5 
Click here to download Supplementary Information: SI1.tif

Supplementary Information
Click here to download Suph 